\title{
Poverty, Income Inequality and Economic Growth in Nigeria (1981-2019)
}

Chinonye Emmanuel Onwuka ( $\nabla$ emmanuelonwuka15@gmail.com )

NA

\section{Research}

Keywords: Poverty, Income Inequality, Economic Growth, ECM, Nigeria

Posted Date: October 18th, 2021

DOI: https://doi.org/10.21203/rs.3.rs-965034/v1

License: (c) (i) This work is licensed under a Creative Commons Attribution 4.0 International License. Read Full License 


\title{
POVERTY, INCOME INEQUALITY AND ECONOMIC GROWTH IN NIGERIA
} (1981-2019)

\author{
Chinonye Emmanuel Onwuka \\ Tel: +2348100543232
}

E-mail: emmanuelonwuka15@gmail.com

\begin{abstract}
This study empirically examined the relationship between poverty, income inequality and economic growth in Nigeria. The study used time series data from National Bureau of Statistics (NBS) and Central Bank of Nigeria (CBN) Statistical Bulletin between the periods from 1981 to 2019. The study employed the use of Augmented Dickey Fuller test, Co integration test and Error Correction technique. The unit root test results indicated that all the variables were stationary at first difference and co-integration test confirmed a long run relationship among the variables. The error correction model shows that about 96 percent of the discrepancy between the actual and the equilibrium value of economic growth is corrected or eliminated each year. The coefficient of determination $\left(R^{2}\right)$ is 0.68 which shows that about 68 percent variations in the economic growth were explained by the independent variables. Furthermore, the BreuschGodfrey Serial Correlation LM Test shows that the probability of the chi-square (2) is 0.2775 and this is greater than 0.05 at $5 \%$ significance level. This therefore confirms the absence of serial correlation. Also, the Breusch-Pagan-Godfrey Heteroscadaticity test indicates that the probability of chi-square (5) is 0.1242 and this is greater than 0.05 at $5 \%$ significant level. This also confirms the absence of heteroscedasticity in the model. From the study, the findings revealed that income inequality has a negative relationship with economic growth in the country while poverty was found to be positively related to economic growth. Similarly, the findings also revealed that poverty and income inequality has an insignificant effect on economic growth in Nigeria. Based on the findings, it can be concluded that poverty and income inequality has not significant relationship with economic growth in Nigeria. Thus, the study concludes that there is need for government of the country to come up with an all-inclusive policy and programme that will be targeted to the poor and give them ample opportunities to improve their welfare.
\end{abstract}

Keywords: Poverty, Income Inequality, Economic Growth, ECM, Nigeria. JEL classification code: I32, D63, 010. 


\section{Introduction}

The foremost macroeconomic objective of governments in almost all countries of the world is the actualization of rapid economic growth (lyoha 2002). The actualization of economic growth leads to higher and ever-increasing economic prosperity. This increasing economic prosperity is empirically linked to greater overall levels of societal progress and improvement. Conversely, without economic growth, economies of nations tend to stagnate thereby deficiency in the provision of the social and economic well-being of their citizens. Economic failure historically causes a loss of trust and social upheaval, frequent and ugly triggers of social conflicts (Loto, 2011).

Poverty is a global issue affecting both developed and developing economies of the world. Generally, it has a challenging effect on developing countries, the sub-Saharan Africa in particular (Addae-Korankye 2014). Poverty is multidimensional in nature and can be evident in different forms such as deficiency of material income, adequate to guarantee good living standard; hunger and under-nutrition; illness; limited education and health services; persistent rise in mortality and morbidity due to sickness; homelessness and insufficient housing; insecure environments and social exclusion and discrimination (Ogbeide, Nwamaka \& Agu, 2015).

Globally, statistics has shown that more than 800 million persons are still living on less than $\$ 1.25$ a day (UNDP 2018). Nigeria is endowed with rich human and natural resources. Given these wealth in economic potentials, it is particularly disturbing and ironical that Nigeria is still rated as one of the poorest countries of the world. According to Statistics from United Nations Development Programme (2020) report reveals that Nigeria ranked number 161 out of 189 countries in Human development. The report puts Nigeria's Human Development Index at 0.539 which is below the prescribed level. Furthermore, statistics also show that as at 2014 , the poverty and unemployment rate in Nigeria were $7.2 \%$ and $7.8 \%$ respectively. As at 2020 , the poverty and unemployment rate has increased to $40.1 \%$ and $33.3 \%$ respectively (National Bureau of Statistics, 2020).

The concept of inequality is fundamental for achieving a sustainable economic growth and development. Inequality is defined as the difference in the standard of living across a population (Gallo, 2002). There are different types of inequality such as: gender, health, wealth and income. However, this study focused on income inequality. Income inequality is defined as the 
disparity in income between rich and poor individuals in a society. According to Clark (2015), over 70 percent of the population in developing countries lives in highly unequal societies. Statistics has shown that the issue of inequality in Nigeria peaked between 1985 and 2004 where the country's Gini coefficient increased from 38.0 to 40.1. Also, in 2010, the coefficient has risen further to 43.0. The Gini coefficient declined to 35.0 As at 2020 (National Bureau of Statistics, 2020).

According to Kolawole and Omobitan (2015), poverty and inequality in Nigeria is a paradox. This implies that poverty level in Nigeria contradicts the country's abundant wealth of both human and human resources. Put differently, there is poverty in the midst of plenty and inequality in the face of economic growth. However, in the pursuit to better the standard of living of Nigerians, several programmes were introduced and implemented at different periods by different governments such as: Operation Feed the Nation of 1977 (OFN), the green revolution of 1980, Directorate of foods, Roads and Rural Infrastructure (DFFRI), the National Directorate for Employment (NDE), Poverty Alleviation Programmes (PAP), up to the National Poverty Eradication Programme (NAPEP). The chief objective of the programmes was amongst other things to reduce and possibly eliminate poverty that has damaged the fabrics of Nigeria economy for decades as well as to reduce the inequality between the haves and the have not.

Prior researches which investigates the link between poverty, income inequality and economic development focuses mostly in developed economies (Knowles, 2005; Nahum, 2005; Davis, 2007; Barro, 2008; Fosu, 2009; Clement; 2010; Cingano, 2014). There is however very few significant study in this area for developing countries like Nigeria. In the Nigerian context, most of the studies (such as Awoyemi, 2005; Oguntuase, 2007; Ogwumike \& Afangidel, 2008; Oyekale, Adeoti, \& Ogunnupe, 2008) focused on either the relationship between inequality and economic growth or poverty and economic growth or between inequality and poverty. It is against this background that this study intends to fill this gap in literature. Hence, this study will examine holistically the effect of income inequality and poverty on economic development in Nigeria.

The remaining of this paper is organized as follows; Section two review theoretical and empirical literatures. The third section focuses on methodology. Section four looks at the presentation and analysis of results while the final section provides conclusion and recommendations. 


\section{Literature Review}

The theoretical basis of the study is based on Kuznets hypothesis. The work of Simon Smith Kuznets (1955) is the most popular and influential framework used to explain the relationship between poverty, income inequality and economic growth. Kuznets (1955) propose that at low levels of per capita income, inequality increases with rising per capita income and eventually reduces in the later stage of development. This could be attributed to the fact that most developing countries are characterized by a traditional agricultural economy with low productivity potential and as it transforms through the process of economic growth. Therefore the relationship between economic growth and income inequality can be represented by an inverted ' $U$ ' pattern referred to as the Kuznets inverted ' $U$ ' hypothesis. Basically, the hypothesis suggests that developing countries would experience a more favorable distribution of income in the process of development though it may be less favorable in the initial stages. The inverted ' $U$ ' hypothesis has motivated many studies on the relationship between income inequality, poverty and economic growth.

According to Aghion and Bolton (1997) Kuznets curve resulted from credit a market imperfection which causes different behavior among the rich and the poor. This is because high income earners have greater access to financial markets (e.g. access to loans and lending services), unlike low income earners who are less likely to gain financial assistance. During the early stages of economic growth, the rich get richer and the poor remain poor; however during later stages of growth, the inequality gap becomes smaller.

Since, the pioneering of the work of Kuznets (1955), several schools of thought have emerged within different ideological perspectives on the nature of relationship between income inequality, poverty and economic growth. Some studies such as Galor and Zeira (1993), Persson and Tabelini (1994) and Alesina and Rodrik (1994) argued that income inequality created economic growth, while others argued that economic expansion would lead to increased income, which ultimately would reduce poverty and income inequality (Aghion, Carol \& Garrcia-Penalosa, 1999). On the other hand, Ravallion (1997) suggested that economic growth could even result in higher income disparity and increase poverty profile. The variation in results is dependent on several factors, such as: lack of accurate data, time span and sensitivity to various econometric approaches (Fawaz et al, 2014).This study however seeks to examine the relationship between poverty, income inequality and economic growth in Nigeria. 


\subsection{Poverty and Economic Growth}

The relationship between poverty and economic growth has been investigated by various studies. Empirical evidences show that countries that have reduced poverty are the ones that have grown the fastest. Poverty, on the other hand, has grown fastest in countries that have stagnated economically. Page (2005) stated that it is difficult to argue that sustained poverty reduction can be achieved alongside economic stagnation or decline, the debate over progrowth versus pro-poor strategies, hinges on the extent to which the average relationship between growth and income distribution conceals important variations that may, ultimately be addressed by public policy. Fosu (2010b) provides global evidence on how economic growth translated into poverty reduction among developing countries. He examined the impact of growth on poverty among Eastern Europe and Central Asia (EECA), South Asia (SAS), subSaharan Africa (SSA), Latin American Countries (LAC) and Middle East and North Africa (MENA) for the period 1981-2005. With the exception of EECA, he found that, poverty levels for all regions decreased for both the $\$ 1.25$ and $\$ 2$ a day poverty lines. He also found that with the exception of MENA, all regions exhibited greater poverty declines in the mid-1990s to 2005 subperiods. Growth since the early 1990s has been substantial, mainly because of the various structural reforms implemented by most developing economies since the early 1980s. He explained further that while growth is a major factor behind changes in poverty levels, income inequality nevertheless is very important because of its effects on the poverty pattern in most countries. He therefore proposed that special attention should be paid to reducing income inequality particularly in countries with highly unfavorable income distribution. ljaiya, ljaiya, Bello

and Ajayi (2011) examine the impact of economic growth on poverty reduction in Nigeria by taking into consideration a time subscript and a difference-in-difference estimator that describes poverty reduction as a function of changes in economic growth. Using a multiple regression analysis, the result obtained indicates that the initial level of economic growth is not prone to poverty reduction, while a positive change in economic growth is prone to poverty reduction. The study suggest that to improve and sustain the rate of economic growth in Nigeria from which poverty could be reduced measures, such as, stable macroeconomic policies, huge investment in agriculture, infrastructural development and good governance are to be implemented. 


\subsection{Income Inequality and Economic Growth}

Several studies have examined the relationship between income inequality and economic growth. Akpolih and Farayibi (2012) conducted a study on the magnitude of inequality as a barrier to economic growth in Nigeria between the periods 1981 to 2009 by employing the use of regression analysis. Their results show that inequality decreases economic growth. They claimed that inequality leads to slower growth through the level of savings and total investment in the economy. Government inefficiency and corruption also had a role to play. Similarly, another study conducted by Awe and Rufus (2012), found out that the Gini coefficient for Nigeria was very high, suggesting high levels of inequality. This was primarily attributed to the level of GDP, education and government expenditure. Generally, studies such as Galor and Zeira (1993); Perotti (1993); Alesina and Rodrik (1994); Persson and Tabellini (1994); Birdsall, Ross and Sabot (1995); Clarke (1995); Alesina and Perotti (1996); De la Croix and Doepke (2003); Josten (2003, 2004); Ahituv and Moav (2003); Viaene and Zilcha (2003); CastellóCliment (2004); Knowles (2005); Davis (2007); Pede, Florax and Partridge (2009) and Ncube, Anyanwu and Hausken (2013) has shown that there is a negative relationship between income inequality and economic growth. On the contrary, studies such as Kaldor (1956); Partridge (1997); Li and Zou (1998); Forbes (2000); and Nahum (2005) are of the opinion that income inequality has a positive impact to economic growth. According to Li and Zou (1998), income inequality may theoretically lead to higher economic growth if public consumption enters the utility function. However, according to a study conducted by Barro (2000), the effect of income inequality on economic growth may differ in developed and developing economies. Furthermore, studies such as Lee and Roemer (1998); Castelló and Domenech (2002); Panizza (2002); Kraay (2002) and Charles-Coll (2013) found no correlation or an inconclusive evidence of any correlation between income inequality and economic growth.

Aigbokhan (2008) found poverty elasticity of growth to be high in Nigeria. The author argued that economic growth in Nigeria propelled poverty, probably due to its non-inclusive nature. The empirical links between the variables were, however, not clearly specified in his models. Fosu (2009) showed that poverty reduction in sub-Saharan Africa had been less-efficient, due to the poor distributional mechanisms of income in the region. Furthermore, a study by Ncube, Anyanwu and Hausken (2013) also found that income inequality reduced economic growth and increased poverty in the Middle East and North African (MENA) region. From the divergences of methods applied in the literature and the results found, it was clear that a wide gap existed in 
the subject matter, particularly in Nigeria. Therefore, establishing both the theoretical and empirical relationship among economic growth, income distribution and poverty are necessary and critical for economic policy making.

\section{Methodology}

\subsection{Model Specification}

The specification of an appropriate econometric model borders on the prevailing economic circumstance(s) and the availability of economic data relating to the variable(s) being examined (Koutusoyiannis, 1997). Therefore, following the works of Hoi Quoc (2010) that stated that growth is a function of poverty and income inequality. This can be expressed mathematically as;

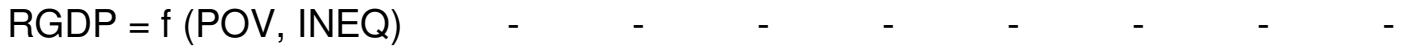

However, equation (2) above can be modified as;

$\mathrm{RGDP}=\mathrm{F}(\mathrm{POV}, \mathrm{INEQ}, \mathrm{POP}, \mathrm{UNEMP}, \mathrm{GCE}) \quad-\quad-\quad-\quad{ }^{-} \quad-\quad-$

The econometric form of the model above is stated as;

$\mathrm{RGDP}_{\mathrm{t}}=\beta_{0}+\beta_{1} \mathrm{POV}_{\mathrm{t}}+\beta_{2} \mathrm{INEQ}_{\mathrm{t}}+\beta_{3} \mathrm{POP}_{\mathrm{t}}+\beta_{4} \mathrm{UNEMP}_{\mathrm{t}}+\beta_{5} \mathrm{GCE}_{\mathrm{t}}+\mathrm{U}_{\mathrm{t}} \quad$

Where; RGDP= Real Gross Domestic Product (GDP at constant prices)

POV $=$ Poverty

INEQ = Income Inequality (proxy by Gini coefficient)

POP = Population

UNEM = Unemployment rate

GCE $=$ Government Capital Expenditure

$\mathrm{U}_{\mathrm{t}}=$ stochastic error term

$\beta_{0}=$ constant term

$\beta_{1}$ to $\beta_{5}=$ coefficients of the variables

A Priori Expectation; $\beta_{1}<0, \beta_{2}<0, \beta_{3}<0, \beta_{4}<0, \beta_{5}>0$

\subsection{Data and Sources}

The study employed the use of annual time series secondary data sourced from the National Bureau of Statistics (NBS) and Central Bank of Nigeria (CBN) statistical bulletin spanning between the periods 1981 to 2019. 


\subsection{Techniques of Analysis}

The study adopts an Ordinary Least Square (OLS) as a statistical tool of analysis. In other to avoid difficulties that may arise while performing regression on time series data with clearly nonstationary series thus leading to spurious regression results, this study however adopted Augmented Dickey Fuller (ADF) test for our unit root in order to attain stationary. The study also employed the use of Johansen co-integration test so as to ascertain the long run relationship between variables employed for this study. Finally, Error Correction Model (ECM) technique is employed to correct any form of dis-equilibrium in the short run.

\section{Presentation and Analysis of Results}

\subsection{Preliminary Analysis}

4.1.1 Descriptive Statistics Table 1: Summary Statistics of Variables

\begin{tabular}{lrrrrrr}
\hline & RGDP & POV & INEQ & POP & UNEMP & \multicolumn{1}{l}{ GCE } \\
\hline Mean & 36920.22 & 45.66154 & 43.87795 & 2.587535 & 3.245897 & 485.8087 \\
Median & 23688.28 & 44.7 & 42.9 & 2.6 & 3.76 & 309.0156 \\
Maximum & 100642.5 & 65.6 & 56 & 2.719177 & 8.39 & 2091.684 \\
Minimum & 13779.26 & 27.2 & 35.1 & 2.495003 & 0 & 4.1001 \\
Std. Dev. & 25139.63 & 8.889397 & 5.313588 & 0.066136 & 2.313411 & 549.6214 \\
Skewness & 1.19479 & 0.043466 & 0.653411 & 0.155975 & 0.204337 & 1.355755 \\
Kurtosis & 3.455558 & 2.78226 & 2.659689 & 1.884776 & 3.022013 & 4.377566 \\
Jarque-Bera & 9.616142 & 0.089323 & 2.963342 & 2.179185 & 0.272186 & 15.0312 \\
Probability & 0.008164 & 0.956321 & 0.227258 & 0.336354 & 0.872762 & 0.000545 \\
Sum & 1439888 & 1780.8 & 1711.24 & 100.9139 & 126.59 & 18946.54 \\
Sum Sq. Dev. & 2.403110 & 3002.812 & 1072.9 & 0.166213 & 203.3711 & 11479181 \\
Observations & 39 & 39 & 39 & 39 & 39 & 39 \\
\hline Source: Author's & Computation & using & & & &
\end{tabular}

Source: Author's Computation using Eviews 10.0, 2021.

The table 1 shows the detail account of the summary statistics for the explained and explanatory variables respectively. The average economic growth as proxied by real GDP is about 36920.22 with standard deviation of 25139.63. In respect of poverty, the mean value is 45.66 with a standard deviation of 8.89 . The analysis of inequality shows a mean value of 43.88 with the value of standard deviation of 5.31. Finally, the mean value of population, unemployment and government capital expenditure are 2.59, 3.25 and 485.81 while their standard deviations are $0.07,2.31$ and 549.6 respectively. Skewness is a measure of asymmetry of the distribution of the series around its mean. Furthermore, the skewness of a normal distribution is zero. Positive skewness implies that the distribution has a long right tail 
and negative skewness implies that the distribution has a long left tail. From the above table we observe that RGDP, POV, INEQ, POP, UNEMP and GCE all have positive skewness and as such they have long right tails. Similarly, kurtosis measures the peakedness or flatness of the distribution of the series. If the kurtosis is above three, the distribution is peaked or leptokurtic relative to the normal and if the kurtosis is less than three, the distribution is flat or platykurtic relative to normal. From table 1 above, it is observed that POV, INEQ and UNEMP are all below three therefore this suggest that these variables are platykurtic while RGDP, POP and GCE are above three therefore this suggest that the variable is leptokurtic. Finally, Jarque-Bera is a test statistic to test for normal distribution of the series. From the table 1 above, the Jarque-Bera for RGDP, POV, INEQ, POP, UNEMP are 9.62, 0.09, 2.96, 2.18, 0.27 and 15.03 respectively. These results show that all the variables except RGDP and GCE are not normally distributed

\subsubsection{Correlation Analysis}

Table 2: Correlation Matrix of Variables

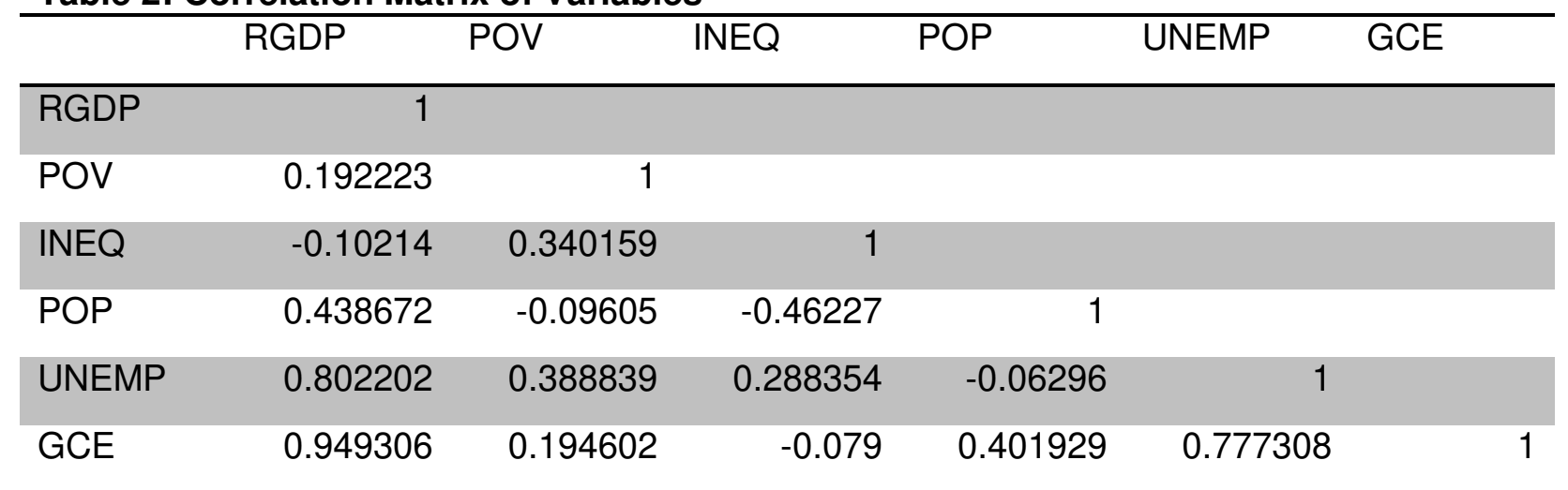

\section{Source: Author's Computation using Eviews 10.0, 2021.}

Table 2 above shows a correlation matrix of variables under consideration. The findings shows that there is a positive relationship between poverty and economic growth in Nigeria. Inequality was found to have a negative relationship with economic growth in Nigeria. Finally, population, unemployment rate and government capital expenditure were found to be positively related to economic growth. 


\subsection{Empirical Analysis}

\subsubsection{Unit Root Test}

Table 3: Unit root Test Results

\begin{tabular}{|c|c|c|c|c|c|c|}
\hline \multirow{2}{*}{ VARIABLES } & \multirow{2}{*}{$\begin{array}{l}\text { ADF TEST } \\
\text { STATISTICS }\end{array}$} & \multicolumn{3}{|c|}{ ADF CRITICAL VALUE } & \multirow{2}{*}{$\begin{array}{l}\text { ORDER OF } \\
\text { INTEGRATION }\end{array}$} & \multirow{2}{*}{ REMARKS } \\
\hline & & $\begin{array}{c}1 \% \\
\text { Level }\end{array}$ & $\begin{array}{l}5 \% \\
\text { level }\end{array}$ & $\begin{array}{l}10 \% \\
\text { level }\end{array}$ & & \\
\hline D(RGDP) & -5.963494 & -3.621023 & -2.943427 & -2.610263 & $\mathrm{I}(1)$ & STATIONARY \\
\hline $\mathrm{D}(\mathrm{POV})$ & -6.068898 & -3.626784 & -2.945842 & -2.611531 & $\mathrm{I}(1)$ & STATIONARY \\
\hline D(INEQ) & -4.806322 & -3.621023 & -2.943427 & -2.610263 & $\mathrm{I}(1)$ & STATIONARY \\
\hline $\mathrm{D}(\mathrm{POP})$ & -6.306703 & -3.626784 & -2.945842 & -2.611531 & $\mathrm{I}(1)$ & STATIONARY \\
\hline D(UNEMP) & -5.605754 & -3.621023 & -2.943427 & -2.610263 & $\mathrm{I}(1)$ & STATIONARY \\
\hline $\mathrm{D}(\mathrm{GCE})$ & -4.728704 & -3.632900 & -2.948404 & -2.612874 & $\mathrm{I}(1)$ & STATIONARY \\
\hline
\end{tabular}

Source: Authors' Computations using Eviews 10.0, 2021.

Table 3 above shows the results of unit root test for Augmented Dickey Fuller Test. It shows that in the process of comparing the test statistic value against the Mackinnon critical value at $1 \%$, $5 \%$ and $10 \%$ level of significance, it was noticed that $\mathrm{D}(\mathrm{POV}), \mathrm{D}(\mathrm{INEQ}), \mathrm{D}(\mathrm{POP}), \mathrm{D}(\mathrm{UNEMP})$ and $D(G C E)$ were found to be stationary at first differenced. Hence, having tested for the stationarity of the variables, we proceed to test for the long run relationships of the variables which give us the co integration result in table 4 below; 
4.2.2 Cointegration Test Result

Table 4: Johansen Cointegration Test Results

\begin{tabular}{|c|c|c|c|c|}
\hline $\begin{array}{l}\text { Hypothesized } \\
\text { No of CE(S) }\end{array}$ & Eigen Value & $\begin{array}{c}\text { Trace } \\
\text { statistic }\end{array}$ & $\begin{array}{c}0.05 \text { critical } \\
\text { value }\end{array}$ & Prob** $^{\star *}$ \\
\hline None * & 0.832783 & 167.1502 & 95.75366 & 0.0000 \\
\hline At most 1 * & 0.681220 & 100.9772 & 69.81889 & 0.0000 \\
\hline At most 2 * & 0.393703 & 58.67679 & 47.85613 & 0.0035 \\
\hline At most 3 * & 0.380172 & 40.16256 & 29.79707 & 0.0023 \\
\hline At most 4 * & 0.316669 & 22.46497 & 15.49471 & 0.0038 \\
\hline At most 5 * & 0.202589 & 8.376268 & 3.841466 & 0.0038 \\
\hline $\begin{array}{l}\text { Hypothesized } \\
\text { No of CE(S) }\end{array}$ & Eigen Value & $\begin{array}{c}\text { Max-Eigen } \\
\text { statistic }\end{array}$ & $\begin{array}{c}0.05 \text { critical } \\
\text { value }\end{array}$ & Prob** \\
\hline None * & 0.832783 & 66.17306 & 40.07757 & 0.0000 \\
\hline At most 1 * & 0.681220 & 42.30038 & 33.87687 & 0.0039 \\
\hline At most 2 & 0.393703 & 18.51423 & 27.58434 & 0.4530 \\
\hline At most 3 & 0.380172 & 17.69760 & 21.13162 & 0.1416 \\
\hline At most 4 & 0.316669 & 14.08870 & 14.26460 & 0.0533 \\
\hline At most 5 * & 0.202589 & 8.376268 & 3.841466 & 0.0038 \\
\hline
\end{tabular}

Source: Authors' Computations using Eviews 10.0, 2021.

Table 4 above depicts the results of Johansen Co integration test. It shows the estimated result of the long run relationship between the variables that is $D(R G D P), D(P O V), D(I N E Q), D(P O P)$, $D(U N E M P)$ and $D(G C E X)$ using the Johansen co integration test. It was observed that the trace statistic in table 4 indicated 6 co-integrating equations at the $5 \%$ level of significance. Similarly, the maximum Eigen value statistic also indicates 3 co-integrating equation at the $5 \%$ level of significance. These results suggest that there is co-integration or long-run relationship among the variables employed in this study. Thus, we further proceed to conduct an error correction test, given the one year time lag used to show the speed of adjustment of the dependent variable to the changes in the explanatory variables in the short run and the result is presented in table 5 below; 


\section{Dependent Variable: D(RGDP)}

\begin{tabular}{lllll}
\hline Variable & Coefficient & Std. Error & t-Statistics & Prob. \\
D(POV) & 46.97383 & 66.10052 & 0.710642 & 0.4832 \\
D(INEQ) & -433.5238 & 392.3949 & -1.104815 & 0.2786 \\
D(POP) & 14196.19 & 79670.32 & 0.178187 & 0.8599 \\
D(UNEMP) & 312.2553 & 684.5115 & 0.456172 & 0.6518 \\
D(GCE) & 15.13405 & 2.428854 & 6.230944 & 0.0000 \\
ECM(-1) & -0.967011 & 0.139302 & -6.941828 & 0.0000 \\
R-Square $=\mathbf{0 . 6 8 3}$ & \multicolumn{2}{c}{ Adjusted R-square =0.580 } & & \\
DW Stat. = 1.992 & F-test = 6.688 & & \\
\hline
\end{tabular}

Source: Authors' Computations using Eviews 10.0, 2021.

Table 5 above depicts that the output of a parsimonious error correction model (ECM). It shows that about 96.7 percent of the discrepancy between the actual and the long run or equilibrium value of real gross domestic product is corrected or eliminated each year. Notice that the coefficient of the ECM has a negative sign as expected and is significant at $1 \%$ probability level. Thus, this validates our earlier position that the variables under study are indeed co-integrated. The coefficient of determination $\left(R^{2}\right)$ is 0.68 which shows that about 68 percent variations in the real gross domestic product were explained by the independent variables. The coefficient of poverty is 46.97 and it shows that a unit increase in the $D(P O V)$ will result to about 46.97 increase in the $D(R G D P)$. The coefficient of income inequality is -433.52 and it shows that a unit increase in the $\mathrm{D}(\mathrm{INEQ})$ will result to about 433.52 decrease in the $\mathrm{D}(\mathrm{RGDP})$. The coefficient of population is 14196.19 and it shows that a unit increase in the $\mathrm{D}(\mathrm{POP})$ will result to about 14196.19 decrease in the $\mathrm{D}(\mathrm{RGDP})$. The coefficient of unemployment rate is 312.23 and it shows that a unit increase in D(UNEMP) will result to about 312.23-unit increase in real GDP. Finally, the coefficient of government capital expenditure is 15.13 and it shows that a unit increase in $\mathrm{D}(\mathrm{GCE})$ will result to about 15.13-unit increase in real GDP. Similarly, the t-test for the intercept, $D(R G D P), D(P O V), D(I N E Q), D(P O P), D(U N E M P)$ and $D(G C E)$ were $0.71,-1.105$, 
$0.178,0.456,6.231$ respectively. By implication, the t-test indicates that poverty rate and inequality has no significantly effect on economic growth in Nigeria at 5 percent level of significance. Similarly, the F-test is 6.688 shows that the overall test is significant. Thus this tells us that the explanatory variables are simultaneously significant in forecasting economic growth in Nigeria. Also, the Durbin-Watson statistics value of 1.992 indicates that there is no autocorrelation in the model.

\subsubsection{Post- Diagnostic Test}

4.2.4.1 Confirmation of the absence of Serial Correlation Table 6: Breusch-Godfrey Serial Correlation LM Test

\section{Breusch-Godfrey Serial Correlation LM Test}

\begin{tabular}{lclc}
\hline F-statistic & 1.091 & Prob. F(2,31) & 0.3485 \\
& & & \\
Obs ${ }^{\star}$ R-squared & 2.56384 & Prob. Chi Square(2) & 0.2775
\end{tabular}

\section{Source: Authors' Computations using Eviews 10.0, 2021.}

$\mathrm{H}_{0}$ : The residuals are not serially correlated

$\mathrm{H}_{1}$ : The residuals are serially correlated

\section{Decision Rule}

Probabilities $>0.05$ accept the null hypothesis

Probabilities $<0.05$ reject the null hypothesis

The above table 6 present the result of Breusch-Godfrey Serial Correlation LM Test. Based on the findings, the probability of the chi-square (2) is 0.2775 and this is greater than 0.05 at $5 \%$ significance level and therefore the null hypothesis is accepted. This implies and therefore confirms the absence of serial correlation 


\subsubsection{Confirmation of Absence of Heteroscedasticity} Table 7: Breusch-Pagan-Godfrey Heteroscedasticity Test

\section{Breusch-Pagan-Godfrey Heteroscedasticity Test}
F-statistic
1.267129
Prob. $F(5,33)$
0.3566

Obs*R-squared

2.913392 Prob. Chi-Square(5)

0.1242

Scaled explained SS

1.867226 Prob. Chi-Square(5)

0.2756

Source: Authors' Computations using Eviews 10.0, 2021.

$\mathrm{H}_{0}$ : Homoscedasticity

$\mathrm{H}_{1}$ : Heteroscedasticity

Decision Rule

Probabilities $>0.05$ accept the null hypothesis

Probabilities $<0.05$ reject the null hypothesis

The above table 7 present the Breusch-pagan-Godfrey Heteroscadaticity test, the probability of chi-square (5) is 0.1242 and this is greater than 0.05 at $5 \%$ significant level and therefore the null hypothesis is accepted. This implies and therefore confirms the absence of heteroscedasticity in the model. In essence, they have constant variance in repeated sampling. 


\subsubsection{Parameter Stability Test (CUSUM Test)}

Fig 1: CUSUM Test

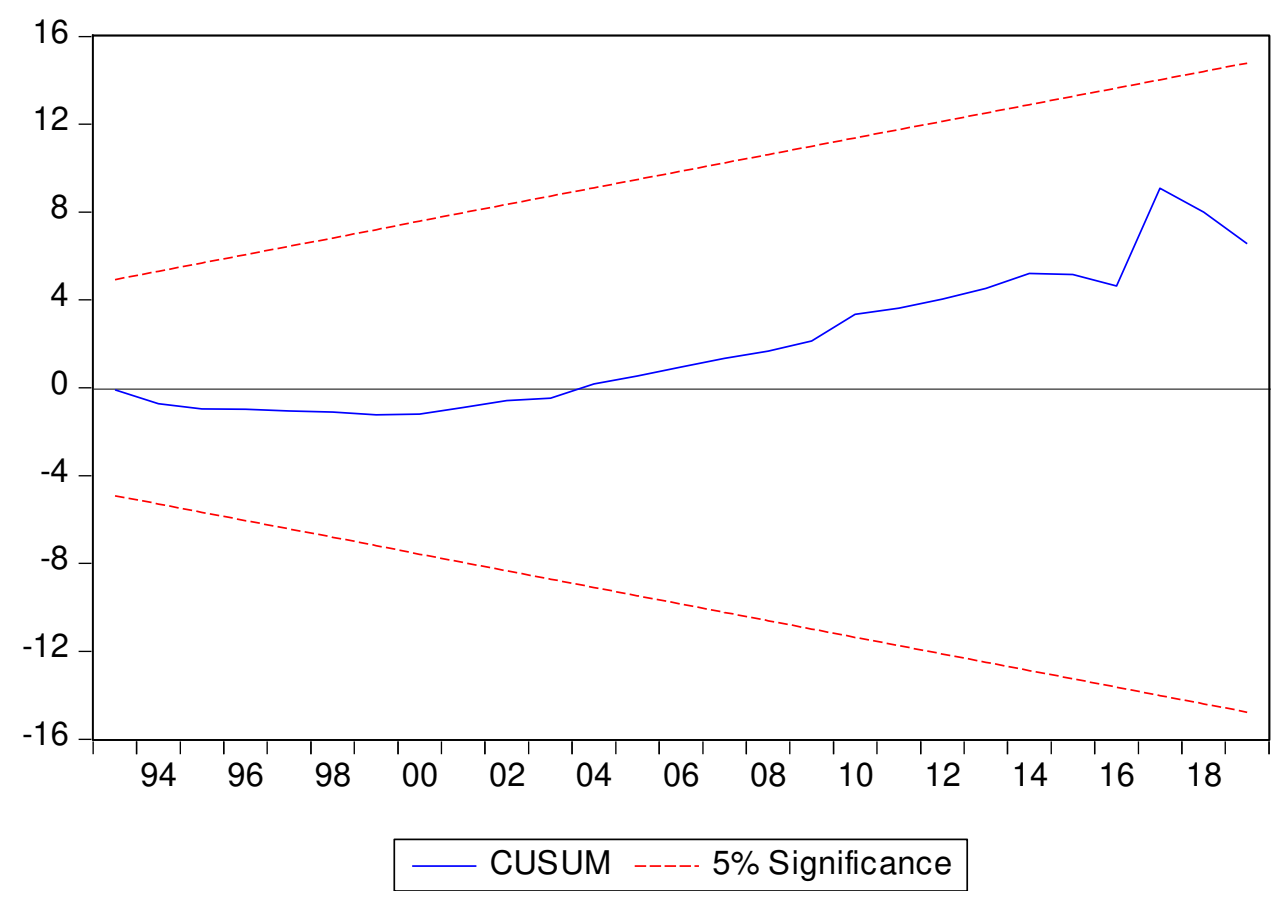

\section{Hypotheses}

There are two hypotheses governing the CUSUM and they are expressed below.

$\mathrm{H}_{0}$ : parameters are stable

$\mathrm{H}_{1}$ : parameters are not stable.

\section{Decision Rule}

If the blue/dotted line is found between/within the two parallel red lines, we accept the null hypothesis (stable) and reject the alternative hypothesis (not stable). But if the blue line is found across/outside the red lines, we accept the alternative hypothesis (not stable) and reject the null hypothesis (stable).

From the figure 1 above, the CUSUM remained within the 5 percent critical lines throughout the whole period thus, signifying parameter stability during the course of assessment. 


\subsection{Conclusion}

This study empirically examined the relationship between poverty, income inequality and economic growth in Nigeria using data spanning between the periods 1981 to 2019, by employing the use of Augmented Dickey Fuller test, Co integration test and Error Correction technique. From the study, the findings revealed that income inequality has a negative relationship with economic growth in the country while poverty was found to be positively related to economic growth. Similarly, the findings also revealed that poverty and income inequality has an insignificant effect on economic growth in Nigeria. Based on the findings, it can be concluded that poverty and income inequality has not significant relationship with economic growth in Nigeria. Thus, the study concludes that there is need for government of the country to come up with an all-inclusive policy and programme that will be targeted at the poor and give them ample opportunities to improve their welfare. Since, most income inequality in the country tends to be obvious and visible in the rural area and places with low social and economic welfare, it therefore means that there is need for the government to provide basic infrastructure such as good road, schools, health care facilities, availability of good water supply and electricity to people in those places. If properly done, will ultimately result to decline in poverty and income inequality in the country. 


\section{Declarations}

\section{Ethics approval and consent to participate}

Not applicable

\section{Consent for Publication}

Not applicable

\section{Availability of data and materials}

The data for this study were sourced from the database of National Bureau of Statistics (NBS) and Central Bank of Nigeria (CBN) Statistical Bulletin (https:/www.cbn.gov.ng).

\section{Competing interests}

The author declares that there are no competing interests associated with this manuscript.

\section{Funding}

I hereby declare that there was no funding received for this manuscript.

\section{Author's contributions}

The author was the overall contributor to the development of all the sections in this manuscript.

\section{Acknowledgements}

The author is highly indebted to the editors and reviewers for their guidance in not only ensuring that this manuscript is scholarly but also gets published accordingly. 


\section{REFERENCES}

Addae-Korankye, A., (2014). Causes of poverty in Africa: A review of literature. American International Journal of Social Science, 3(7), 147-153.

Aghion, P. \& Bolton. P. (1997). A Theory of Trickle down Growth and Development. Review of Economic Studies, 64(1), 151-172.

Akpolih, A.R. \& Farayibi, A.O. (2012). Economic growth and inequality in Nigeria: Magnitudes and challenges by Roland Avura Akpoilih, Adesoji Oladapo Farayibi: SSRN: Retrieved from https://papers.ssrn.com/sol3/papers.cfm?abstract.pdf

Awoyemi, B.T. (2005). Explaining Income Inequality in Nigeria: A Regression Based Approach. Journal of Economics and Rural Development, 4 (6), 45-59.

Awe, A.A. \& Rufus, O.O. (2012). Determinants of income distribution in the Nigeria economy: 1977-2005. International Business and Management, 5(1), 126-137.

Barro, R.J. (2008). Inequality and growth revisited. Asian development Bank working papers 11.

Birdsall, N., Ross, D., \& Sabot, R. (1995). Inequality and Growth Reconsidered: Lessons from East Asia. The World Bank Economic Review, 9(3), 477- 508

Cingano, F. (2014). Trends in Income- inequality and its Impact on Economic Growth. OECD Social, Employment and Migration Working Papers, No. 163, OECD Publishing.

Clarke, G. (1995). More Evidence on Income Distribution and Growth. World.

Clark, C. (2015). Capital formation in an economy: Meaning, significance and process. Available at: $\quad$ http://www.economicsdiscussion.net/capitalformation/capital-formation-in-aneconomy-meaning-significance-andprocess/12981 [Accessed 28 Jan. 2017].

Davis, L.S. (2007). Explaining the Evidence on Inequality and Growth: Informality and Redistribution. Journal of Macroeconomics, 7(1), 1-35.

Fawaz, F., Rahnama, M. \& Valcarcel, V.J. (2014). A refinement of the relationship between economic growth and income inequality. Applied Economics, 46(27), 3351-3361.

Fosu, A. K. (2009). Inequality and the Impact of Growth on Poverty: Comparative Evidence for Sub-Saharan Africa. Journal of Development Studies, 45(5), 726-745.

Fosu, K. A. (2010a). Does Inequality Constraint Poverty Reduction Programs? Evidence from Africa. Journal of Policy Modelling. 32 (10), 818-827.

Fosu, K. A. (2010b). Growth, Inequality and Poverty Reduction in Developing Countries: Recent Global Evidence, Centre for the Study of African Economies (CSAE) WPS/201107.

Fosu, K. A. (2010c). Inequality, Income and Poverty: Comparative Global Evidence, Social Science Quarterly, vol. 91, No. 5, December 2010.

Galor, O., \& Zeira, J., (1993). Income distribution and macroeconomics. Review of Economics, $60(1), 35-52$.

Gallo, C. (2002). Economic growth and income inequality. Retrieved from: https://www.bartlett.ucl.ac.uk/dpu/publications/latest/publications/dp.pdf.

Hoi Quoc, L. (2010). The linkages between Growth, poverty and Inequality in Vietnam: An empirical Analysis. 
Iyoha, M.A (2002). An econometric model of the Nigerian economy: In Milton A lyoha \& Chris O Itsede (eds.) The Nigerian Economy: Structure, Growth and Development, Ibadan: Mindex Publishers.

Knowles, S (2005). Inequality and economic growth: The Empirical Relationship Reconsidered in the Light of Comparable Data. The Journal of Development Studies, 41(1), 135-159.

Kolawole, B. \& Omobitan, A. (2015). Poverty, inequality and growth in Nigeria: An empirical evidence, Department of Economics, Faculty of Social Sciences, Lagos State University, Ojo, Lagos.

Koutsoyiannis, A. (1997). Theory of econometrics. An introductory exposition of econometric methods. London: Macmillan Press Limited.

Kuznets, S. (1955). Economic Growth and Income Inequality. American Economic Review, $45(1), 1-27$.

Loto, M.A. (2011). Impact of Government Sectoral Expenditure on Economic Growth. Journal of Economics and International Finance, 3(11), 646-652.

Nahum, R. A. (2005). Income inequality and Growth; A panel study of Swedish Countries 19602000, Arbetstrapport. Institutes for Future Studies.

Ogbeide, O., Nwamaka, E \& Agu, D. (2015). Poverty and inequality in Nigeria. Asian economic and financial review, 5(3), 439-452.

Ogwumike, F.O., \& Afangideh, U. J. (2008). Financial Development and Income Distribution in Nigeria. Journal of Monetary and Economic Integration, 8(1), 63-89.

Oguntuase, A. (2007). An Empirical Investigation into the Determinants of Income Distribution in the Nigerian Manufacturing Sector (Unpublished M.Sc Thesis) Ekiti State University.

Oyekale, A. S., Adeoti, A. I., \& Ogunnupe, T.O. (2008). Sources of Income Inequality and Poverty in Rural and Urban Nigeria. Paper Presented at the 3rd Annual Workshop of Poverty and Economic Policy (PEP) Network Dakar, Senegal (11th -20th June 2004).

Persson, T. \& Tabellini, G. (1994). Is Inequality Harmful for Growth? American Economic Review, 84(3), $600-621$.

Ravallion, M. (1997). Can high inequality countries escape poverty EL. Available at: https://blogs.commons.georgetown.edu/economicsofpoverty/files/2015/12/Canhighinequality-countries-escape-poverty-EL.pdf (Accessed: 18 October 2016).

National Bureau of Statistics (2020). National bureau of statistics annual abstract of statistics. Abuja: NBS Press.

UNDP. (2018). Human development indices and indicators. Statistical Update, Briefing note for countries on the 2018 Statistical Update.

United Nation Development Program (2020). Human Development Report (HDIs) 2020, UN, New York. 
